\title{
Index to Volume 8, 2006
}

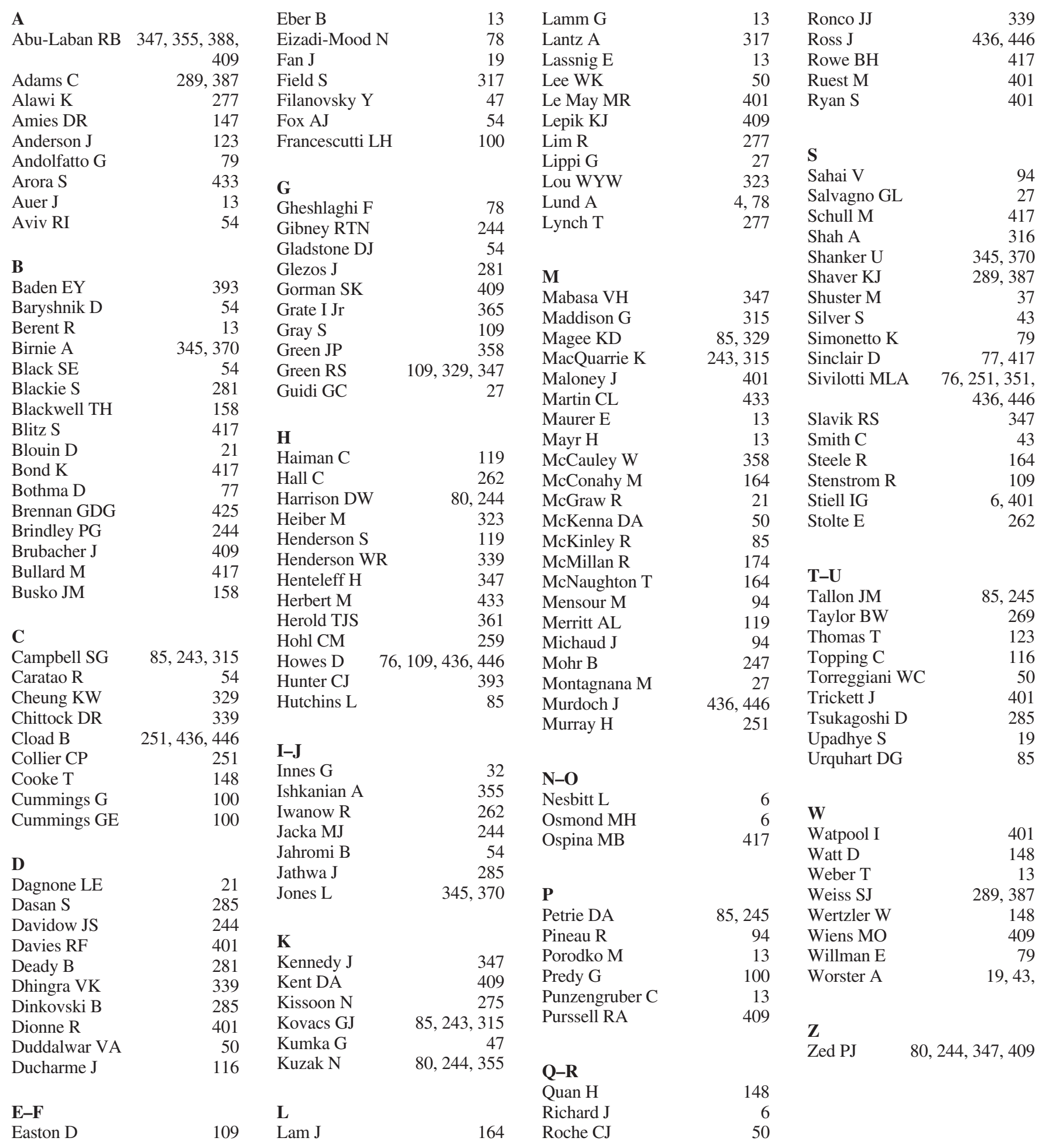

